\title{
О ПРИВЛЕЧЕНИИ ВОЕННОСЛУЖАЩИХ К ДИСЦИПЛИНАРНОЙ ОТВЕТСТВЕННОСТИ ЗА СОВЕРШЕНИЕ АДМИНИСТРАТИВНОГО ПРАВОНАРУШЕНИЯ, БЕЗ ПРОИЗВОДСТВА ПО ДЕЛУ ОБ АДМИНИСТРАТИВНОМ ПРАВОНАРУШЕНИИ
}

\author{
К. А. Стоноженко \\ Санкт-Петербургский военный ордена Жукова институт войск \\ национальной гвардии Российской Федеращии \\ Р. Р. Фаисханов \\ Саратовская государственная юридическая академия \\ Поступила в редакцию 11 мая 2021 г.
}

\begin{abstract}
Аннотация: анализируются основания и порядок привлечения военнослужащих Российской Федерации к дисииплинарной ответственности за совершение адлинистративных правонарушений, за которые военнослужащие в соответствии с Кодексом Российской Федерации об адлинистративных правонарушениях несут дисииплинарную ответственность.
\end{abstract}

Ключевые слова: военнослужащие, адлинистративные правонарушения, дисциплинарная ответственность, полнолочия.

\begin{abstract}
: the article analyzes the grounds and procedure for bringing military personnel of the Russian Federation to disciplinary responsibility for committing administrative offenses, for which military personnel are subject to disciplinary responsibility in accordance with the Code of Administrative Offenses of the Russian Federation.
\end{abstract}

Key words: military personnel, administrative offenses, disciplinary responsibility, powers.

В отечественном государстве военная служба по контракту представляет собой особый вид федеральной государственной службы, при этом лица, имеющие статус военнослужащих, реализуют конституционно значимые функции, что, в целом, предопределяет их специальный правовой статус, включая основания и условия привлечения их к ответственности ${ }^{1}$.

В настоящее время существует значительное число работ, посвящен140 ных исследованию тем дисциплинарной ${ }^{2}$ и административной ответствен-

${ }^{1}$ См.: Определения Конституционного Суда Российской Федерации : от 28 мая 2013 г. № 732-О, от 14 января 2014 г. № 94-О, от 15 октября 2018 г. № 2520-О. Документы опубликованы не были. Доступ из справ.-правовой системы «КонсультантПлюс».

${ }^{2}$ См., например: Харитонов С. С. О некоторых аспектах привлечения военнослужащих к дисциплинарной ответственности за совершение грубых дисциплинарных проступков (по материалам судебной практики) // Военное право. 2020. № 2 (60). С. 162 ; Казаков В. Н., Туганов Ю. Н. Дисциплина и дисциплинарная ответственность военнослужащих в публично-правовой сфере : соотношение понятий // Там же. 2019. № 4 (56). С. 165.

(c) Стоноженко К. А., Фаисханов Р. Р., 2021 
ности военнослужащих ${ }^{3}$. Вместе с тем необходимо заметить, что вопрос привлечения военнослужащих к дисциплинарной ответственности за совершение административных правонарушений, за которые военнослужащие в соответствии с КоАП РФ несут дисциплинарную ответственность (далее - административные правонарушения), при условии отсутствия производства по делу об административном правонарушении, до настоящего времени в научных работах не подвергался детальной проработке. Кроме того, анализ правоприменительной деятельности свидетельствует, что как среди воинских должностных лиц, пользующихся дисциплинарной властью, так и в судебной практике отсутствует единообразное толкование порядка привлечения военнослужащих к дисциплинарной ответственности за совершение административных правонарушений.

Одним из ярких подтверждений приведенных доводов является следующий пример, произошедший в одной из военных образовательных организаций высшего образования (далее - ВООВО). Так, в ходе разбирательства, проведенного должностными лицами ВООВО 10 октября 2019 г., был установлен фракт потребления курсантом Б. запрещенных наркотических средств, т. е. состав административного правонарушения, предусмотренного ч. 1 ст. 6.9 КоАП РФ (потребление наркотических средств без назначения врача), за совершение которого военнослужащие в соответствии с ч. 1 ст. 2.5 КоАП РФ, несут дисциплинарную ответственность.

Командованием ВООВО было принято решение о передаче материалов по указанному выше разбирательству в военную комендатуру, где определением дознавателя от 21 октября 2019 г. в отношении Б. было возбуждено дело об административном правонарушении, предусмотренном ч. 1 ст. 6.9 КоАП РФ, и назначено административное расследование.

В последующем постановлением врио начальника отдела дознания военной комендатуры от 25 октября 2019 г. производство по делу об административном правонарушении в отношении Б. было прекращено на основании ч. 2 ст. 24.5 КоАП РФ, а материалы возвращены в ВООВО для привлечения курсанта Б. к дисциплинарной ответственности ${ }^{4}$.

Таким образом, воинские должностные лица, установив наличие признаков административного правонарушения, направили материалы в военную комендатуру, заведомо зная, что должностным лицом военной комендатуры будет вынесено постановление о прекращении производства по делу об административном правонарушении, а все материалы

${ }^{3}$ См., например: Назарова И. С., Шеншин В. М. Особенности привлечения военнослужащих к административной ответственности // Военное право. 2015. № 2 (34). С. 64 ; Кузнецов В. И. Особенности привлечения военнослужащих к административной ответственности // Военно-юрид. журнал. 2021. № 1. С. 8.

${ }^{4}$ Апелляционное определение 1-го Западного окружного военного суда от 21 мая 2020 г. по делу № 33а-196/2020. Определением Кассационного военного суда от 17 ноября 2020 г. № 88а-2239/2020 по делу № 2a-29/2020 данное Апелляционное определение оставлено без изменения. Документы опубликованы не были. Доступ из справ.-правовой системы «КонсультантПлюс». 


\section{Вестник ВГУ. Серия: Право}

дела будут возвращены в ВООВО для привлечения военнослужащего к дисциплинарной ответственности.

По нашему мнению, такая ситуация обусловлена отсутствием понимания полномочий командиров воинских частей самостоятельно принимать решения о проведении разбирательств по фракту совершения грубых дисциплинарных проступков подчиненными военнослужащими при выявлении признаков административных правонарушений.

Аналогичный порядок действий воинских должностных лиц усматривается также из анализа Апелляционного определения 1-го Западного окружного военного суда от 21 мая 2020 г. по делу № 33a-166/20205, peшений Южного окружного военного суда от 19 августа 2020 г. по делу № 12-106/2020, Санкт-Петербургского гарнизонного военного суда от 12 фревраля 2020 г. по делу № 2А-48/2020, 109-го гарнизонного военного суда от 27 ноября 2019 г. по делу № 2А-77/2019, а также Иркутского гарнизонного военного суда от 21 августа 2019 г. по делу № 2A-100/20196 , что свидетельствует о наличии системного характера указанных действий.

Помимо этого, позиция об отсутствии правомочности воинских должностных лиц установления в ходе проведения разбирательства по фракту совершения грубого дисциплинарного проступка состава административного правонарушения встречается и в судебной практике.

Так, разбирательство по фракту совершения военнослужащим грубого дисциплинарного проступка - административного правонарушения, назначенное и проведенное уполномоченными воинскими должностными лицами, суд посчитал незаконным, а отсутствие производства по делу об административном правонарушении послужило основанием для отмены правового акта командира воинской части о применении к военнослужащему дисциплинарного взыскания ${ }^{7}$.

Вместе с тем считаем, что в случае совершения военнослужащим административного правонарушения обстоятельства его совершения как основания для привлечения к дисциплинарной ответственности подлежат выяснению командованием воинской части в рамках производства по материалам о грубом дисциплинарном проступке.

Так, законодательно определено, что военнослужащие могут привлекаться к уголовной, гражданско-правовой, материальной, административной и дисщиплинарной ответственности ${ }^{8}$.

5 Документ опубликован не был. Доступ из справ.-правовой системы «КонсультантПлюс».

${ }^{6}$ Документы опубликованы не были. Доступ из интернет-ресурса «Судебные и нормативные правовые акты РФ (СудАкт)».

${ }^{7}$ Решение Владивостокского гарнизонного военного суда Приморского края от 29 июля 2019 г. по делу № 2А-263/2019. Документ опубликован не был. Доступ из интернет-ресурса «Судебные и нормативные правовые акты РФ (СудАкт)».

${ }^{8}$ О статусе военнослужащих : федер. закон от 27 мая 1998 г. № 76-ФЗ (в ред. от 08.12.2020) // Собр. законодательства Рос. Федерации. 1998. № 22. Ст. 2331 ; 2020. № 50 (ч. 3). Ст. 8074. 
В силу ст. 47 Дисциплинарного устава Вооруженных сил РФ9 за административные правонарушения военнослужащие несут дисциплинарную ответственность, за исключением административных правонарушений, за которые они несут ответственность на общих основаниях.

При этом в соответствии с п. 2 ст. 28.5 Закона «О статусе военнослужащих» и Перечнем грубых дисциплинарных проступков военнослужащих ${ }^{10}$ административные правонарушения являются грубыми дисциплинарными проступками.

Кроме того, ст. 81 Дисциплинарного устава содержит императивные предписания, в соответствии с которыми непосредственные командиры (начальники) обязаны немедленно докладывать командиру воинской части о получении данных о совершении подчиненными им военнослужащими грубых дисциплинарных проступков.

В свою очередь, командиры воинских частей обязаны назначать разбирательства по факту совершения подчиненными военнослужащими грубых дисциплинарных проступков, которые заканчиваются составлением протоколов.

Содержание названных правовых норм подтверждает правомочие командиров воинских частей, установив наличие признаков административного правонарушения, проводить разбирательство по факту совершения грубого дисциплинарного проступка.

Подтверждение нашим выводам находим в определении Конститу-

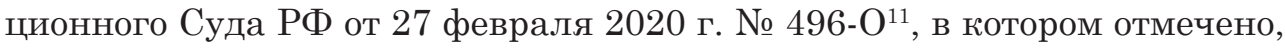
что военнослужащий, привлекаемый к дисциплинарной ответственности, имеет фактически те же права, что и лицо, в отношении которого ведется производство по делу об административном правонарушении. В связи с этим воинские должностные лица уполномочены на проведение разбирательства по факту совершения грубого дисциплинарного проступка при выявлении признаков административного правонарушения. Например, в соответствии КоАП РФ военнослужащие привлекаются к дисциплинарной ответственности за следующие административные правонарушения:

нарушение запрета курения табака, потребления никотинсодержащей продукции или использования кальянов (ст. 6.24);

нарушение законодательства Российской Федерации в области персональных данных (ст. 13.11);

нарушение правил защиты информации (ст. 13.12);

умышленное повреждение или срыв печати (пломбы) (ст. 19.2);

${ }^{9}$ Об утверждении общевоинских уставов Вооруженных сил Российской Федерации : указ Президента РФ от 10 ноября 2007 г. № 1495 // Собр. законодательства Рос. Федерации. 2007. № 47 (ч. 1). Ст. 5749.

${ }^{10}$ Приложение № 7 к Дисциплинарному уставу Вооруженных сил РФ : утв. Указом Президента РФ от 10 ноября 2007 г. № 1495 // Собр. законодательства Рос. Федерации. 2007. № 47 (ч. 1). Ст. 5749.

11 Документ опубликован не был. Доступ из справ.-правовой системы «КонсультантПлюс». 
мелкое хулиганство (ст. 20.1);

нарушение установленного порядка организации либо проведения собрания, митинга, демонстрации, шествия или пикетирования (ст. 20.2);

нарушение требований пожарной безопасности (в месте военной службы) (ст. 20.4);

невыполнение правил поведения при чрезвычайной ситуации или угрозе ее возникновения (ст. 20.6.1 КоАП);

потребление (распитие) алкогольной продукции в запрещенных местах либо потребление наркотических средств или психотропных веществ, новых потенциально опасных психоактивных веществ или одурманивающих веществ в общественных местах (ст. 20.20);

появление в общественных местах в состоянии опьянения (ст. 20.21).

K тому же добавим, что непринятие командиром в пределах его компетенции необходимых мер по предупреждению или пресечению дисциплинарного проступка, совершенного подчиненным ему по службе военнослужащим, привлечению военнослужащего к дисциплинарной ответственности за совершение дисциплинарного проступка либо сокрытие командиром информации о совершении подчиненным ему по службе военнослужащим административного правонарушения или дисциплинарного проступка также являются грубыми дисциплинарными проступками.

Вместе с тем в соответствии с позицией Верховного Суда РФ $\Phi^{12}$ совершение одного из грубых дисциплинарных проступков признается значительным (существенным) отступлением от требований законодательства о воинской обязанности и военной службе, является невыполнением условий контракта и представляет собой самостоятельное основание для досрочного увольнения с военной службы. нарного взыскания, так и по результатам аттестации военнослужащего.

На основании изложенного приходим к выводу о том, что совершение одного из таких административных правонарушений, как использование никотинсодержащей продукции (курение) или потребление (распитие) алкогольной продукции в запрещенных местах, мелкое хулиганство, нарушение требований пожарной безопасности (в месте военной службы), невыполнение правил поведения при чрезвычайной ситуации или угрозе ее возникновения, появление в общественных местах в состоянии опьянения, может быть достаточным основанием для последующего досрочного увольнения военнослужащего с военной службы.

При указанных обстоятельствах, по нашему мнению, необходима работа по предупреждению недопущения несоразмерности применяемых санкций совершенным военнослужащими правонарушениям как в случае поступления в воинскую часть постановления о прекращении произ-

${ }^{12} \mathrm{O}$ практике применения судами законодательства о воинской обязанности, военной службе и статусе военнослужащих : постановление Пленума Верховного Суда РФ от 29 мая 2014 г. № 8 (в ред. от 28.06.2016) // Рос. газета. 2014. 4 июня. 
водства по делу об административном правонарушении, так и при условии проведения разбирательства должностными лицами воинской части по фракту грубого дисциплинарного проступка - совершение административного правонарушения, за которое военнослужащие привлекаются к дисциплинарной ответственности.

Наши выводы по существу оснований для досрочного увольнения с военной службы не претендуют на то, чтобы быть истинными в конечной инстанции, но являются приглашением к дальнейшей научной дискуссии по вопросу о привлечении военнослужащих к дисциплинарной ответственности за совершение административных правонарушений.

\section{Библиографический список}

Казаков В. Н., Туганов Ю. Н. Дисциплина и дисциплинарная ответственность военнослужащих в публично-правовой сфере : соотношение понятий // Военное право. 2019. № 4 (56). С. 164-174.

Кузнецов В. И. Особенности привлечения военнослужащих к административной ответственности // Военно-юридический журнал. 2021. № 1. C. $7-11$.

Назарова И. С., Шеншин В. М. Особенности привлечения военнослужащих к административной ответственности // Военное право. 2015. № 2 (34). C. 63-72.

Харитонов С. С. О некоторых аспектах привлечения военнослужащих к дисциплинарной ответственности за совершение грубых дисциплинарных проступков (по материалам судебной практики) // Военное право. 2020. № 2 (60). C. 162-167.

\section{References}

Kazakov V. N., Tuganov Yu. N. Discipline and disciplinary responsibility of military personnel in the public-legal sphere: correlation of concepts // Military law. 2019. № 4 (56). P. 164-174.

Kuznetsov V. I. Features of bringing military personnel to administrative responsibility // Military-legal journal. 2021. № 1. P. 7-11.

Nazarova I. S., Shenshin V. M. Features of bringing military personnel to administrative responsibility // Military law. 2015. № 2 (34). P. 63-72.

Kharitonov S. S. On some aspects of bringing military personnel to disciplinary responsibility for committing gross disciplinary offenses (based on the materials of judicial practice) // Military law. 2020. № 2 (60). P. 162-167.

Санкт-Петербургский военный ордена Жукова институт войск наииональной гвардии Российской Федерации

Стоноженко К. А., кандидат юридических наук, доиент, залеститель начальника кафбедры гражданского права, полковник юстиции

E-mail: stonozhenkok@mail.ru
St. Petersburg Military Order of Zhukov Institute of the National Guard of the Russian Federation

E-mail: emilzola1990@yandex.ru

Stonozhenko K. A., Candidate of Legal Sciences, Associate Professor, Deputy Head of the Civil Law Department, Colonel of Justice

E-mail: stonozhenkok@mail.ru 
Вестник ВГУ. Серия: Право

Саратовская государственная юридическая акаделия

Фаисханов Р. Р., аспирант кафбедрь административного и муниципального права

E-mail: emilzola1990@yandex.ru
Saratov State Law Academy

Faiskhanov R. R., Post-graduate Student of the Administrative and Municipal Law Department

E-mail: emilzola1990@yandex.ru 